\title{
Anti-candida activity of murine bronchoalveolar lavage fluid
}

\author{
L. P. SAMARANAYAKE* $\dagger$, R. S. TOBGI* and T. W. MACFARLANE* \\ "Department of Oral Sciences, Glasgow Dental Hospital and School, 378 Sauchiehall Street, Glasgow G2 3JZ and \\ †Oral Biology Unit, Faculty of Dentistry, The University of Hong Kong, 34 Hospital Road, Hong Kong
}

\begin{abstract}
Summary. Respiratory secretions provide an efficient method for protecting the large surface area of the lower respiratory tract. To determine whether lung secretions contribute to antifungal defences, murine bronchoalveolar lavage fluid (BLF) was tested for anti-candidal activity against 49 oral and vaginal isolates belonging to six different Candida species. The yeasts were incubated in unconcentrated, cell-free lavage fluid from Sprague-Dawley rats and then cultured quantitatively to measure residual viability. Experiments with $C$. albicans indicated that sensitivity to BLF increased in a time- and dose-dependent manner. This activity was heat-stable $\left(56^{\circ} \mathrm{C}\right)$ and consistent, irrespective of whether the BLF was derived from rats inoculated (orally) with candida or the uninoculated controls. Of the Candida spp. examined, C.albicans was the most susceptible followed by $C$.parapsilosis and $C$. tropicalis, whereas $C$. krusei, $C$. guilliermondii and C. glabrata were highly resistant. However, there were differences in susceptibility to BLF among different isolates within a given species. These results indicate that a heat-stable, soluble factor(s) in murine lavage fluid may suppress candidal colonisation of the lower respiratory tract and contribute to the defence mechanisms of the lungs.
\end{abstract}

\section{Introduction}

Pulmonary infections with Candida albicans and other Candida spp. may develop in compromised patients with impaired host defences, leading to significant morbidity and mortality. ${ }^{1}$ Both aspiration of oropharyngeal flora and haematogenous dissemination from remote infections play a critical role in the pathogenesis of such disease. ${ }^{2}$ As oropharyngeal candidiasis is extremely common in immunosuppressed patients ${ }^{3}$ and is an important risk factor in the development of candida pneumonia, a murine model has been developed to investigate pulmonary defences against $C$. albicans. ${ }^{4}$ With this model, Nugent and Fick demonstrated the presence of a soluble. heat-stable protein with anti-Candida activity in murine bronchoalveolar lavage fluid ${ }^{5}$ (BLF). Others too have monitored the intra-alveolar killing of staphylococci exposed to BLF and obtained evidence that inhaled staphylococci are killed mainly by bronchoalveolar secretions, rather than by alveolar macrophages. ${ }^{6}$

The aforementioned studies by Nugent and Fick were conducted with only three isolates of $C$. albicans and one isolate each of four other Candida spp.

Received 24 May 1993; revised version accepted 11 Nov. 1993. † Correspondence should be sent to Dr L. P. Samaranayake, Oral Biology Unit, Faculty of Dentistry, The University of Hong Kong, 34 Hospital Road, Hong Kong.
However, it is known that there are wide inter- and intra-species variations in the susceptibility of Candida spp. to non-specific defence factors such as lysozyme ${ }^{7}$ and lactoferrin. ${ }^{8}$ The aim of this study was to evaluate the antifungal activity of murine BLF against a panel of 49 oral and vaginal isolates of six different species of Candida by a sensitive assay procedure.

\section{Materials and methods}

\section{Isolates and growth conditions}

A total of 49 clinical isolates of Candida spp. from the routine microbiology services of the Glasgow Dental Hospital and School and Glasgow Royal Infirmary were used. Most of the isolates were recovered from patients with candida-associated denture stomatitis and burning mouth syndrome; the remainder were from patients with vaginal candidosis and from asymptomatic carriers. All isolates were identified by sugar assimilation ${ }^{9}$ and the germ-tube test. ${ }^{10}$ The Candida spp. thus identified and used in the study were $C$. albicans (22 isolates), C. glabrata (three), C. tropicalis (seven), C. parapsilosis (five), C. krusei (seven) and C. guilliermondii (five).

Stock cultures were maintained on Sabouraud's Glucose Agar (SGA; Oxoid) at $4^{\circ} \mathrm{C}$ and subcultured every 2 weeks. 


\section{Animals and BLF}

Twelve young adult male Sprague-Dawley rats, 200-300 g in weight (Bantin and Kingman, Glasgow) that were involved in preliminary experiments to study oral candidosis were investigated. They were split into a control group comprising five animals (CR 1-5) and a test group, comprising seven animals (TR1-7). Briefly, the experimental schedule used for the test group of rats was as follows. ${ }^{11}$ Before the rats were challenged with a yeast, they were given water containing tetracycline hydrochloride $0.1 \%$ and $30 \mathrm{~g}$ of a carbohydrate-rich diet (carbohydrate $62 \%$, proteins $33 \%$, vitamins and minerals $5 \%$ )/animal/day, for 7 days. Thereafter the rats continued to receive the carbohydrate-rich diet, but the concentration of tetracycline in the drinking water was reduced to $0.01 \%$ until they were killed. The rats were inoculated orally with $3 \mathrm{ml}$ of $C$. albicans GDHa15 suspension, (1-2) $\times$ $10^{7}$ yeasts $/ \mathrm{ml}$, three times/day on every alternate day in the first week and, subsequently, two doses on every alternate day until the end of week 4 .

The control group of animals comprised five rats who received neither the carbohydrate-rich diet nor tetracycline hydrochloride and were not inoculated with the yeast.

BLF was collected as described by Nugent and Fick. ${ }^{5}$ Rats in the test and control groups were killed by intraperitoneal barbiturate (Nembutal) at the end of week 5 (in the case of the test rats, 1 week after the last inoculation with Candida spp.). The lungs, heart and trachea were carefully dissected out as a single block into a numbered, sterile petri dish. A tracheotomy was made with a blunt 22-gauge needle, and then a plastic catheter was inserted into the trachea and secured with a tie. Each lung was infused twice with 5 $\mathrm{ml}$ of sterile phosphate-buffered saline (PBS; $0.1 \mathrm{M}, \mathrm{pH}$ $7 \cdot 2$ ) and the resultant lavage was aspirated. Recoveries ranged from 60 to $80 \%$.

The BLF was collected into a conical tube and centrifuged immediately at $300 \mathrm{~g}$ for $10 \mathrm{~min}$ to remove macrophages and large particles. The supernate was dispersed into $1-\mathrm{ml}$ volumes in sterile $7-\mathrm{ml}$ bottles which were marked and stored at $-20^{\circ} \mathrm{C}$ until use. The clear, cell-free supernate of the BLF was used for the assay as described below.

\section{Candidacidal assay}

Candida spp. were grown on Sabouraud's Dextrose Agar plates (SDA; Oxoid) incubated aerobically at $37^{\circ} \mathrm{C}$ for $24 \mathrm{~h}$. A loopful of the confluent growth was transferred to $10 \mathrm{ml}$ of Sabouraud's Broth Medium (Oxoid) supplemented with glucose $4 \%$ and incubated at $37^{\circ} \mathrm{C}$ on an orbital incubator at $100 \mathrm{rpm}$ for $18 \mathrm{~h}$. The growth was harvested by centrifugation at $1500 \mathrm{~g}$ for $10 \mathrm{~min}$. The cells were washed twice in $10 \mathrm{ml}$ of sterile PBS and adjusted to give a final concentration of $(2-2 \cdot 5) \times 10^{6}$ yeast cells $/ \mathrm{ml}$. The number of yeast cells/ml was monitored in all experiments by micro- scopic counting in an improved Neubauer haemocytometer chamber (Hawksley).

The effect of BLF on the viability of Candida spp. was tested by mixing $0.25 \mathrm{ml}$ of BLF and $0.25 \mathrm{ml}$ of a yeast suspension containing $(2-2 \cdot 5) \times 10^{6}$ yeast $/ \mathrm{ml}$, prepared as above, in a $7-\mathrm{ml}$ bottle, giving a total volume of $0.5 \mathrm{ml}$. The bottles were incubated at $37^{\circ} \mathrm{C}$ in an orbital incubator (Gallenkamp, Loughborough) at $80 \mathrm{rpm}$ for $0,30,60$ and $120 \mathrm{~min}$.

Each sample was examined microscopically for the presence of agglutination or clumping of yeast cells before the quantitative analysis. The number of viable yeasts in the suspension was determined with a spiral plater system (Spiral System Marketing: Baltimore, MD, USA). In this system, $50 \mu$ of each sample was inoculated on to a SDA plate and incubated at $37^{\circ} \mathrm{C}$ for $18 \mathrm{~h}$ and the resultant number of cfu of Candida were then counted with a Gallenkamp colony counter (Gallenkamp, Berlin, Germany). The results were expressed as percentage survival rate of organisms by the formula:

Percentage survival rate $=\mathrm{cfu}$ of test suspension/ $\mathrm{cfu}$ of control suspension $\times 100$.

\section{Comparison of serum and $B L F$}

It is known that serum contains heat-stable agglutinating factors that cause a reduction in the viable count of Candida spp., which appears to be due to clumping of yeast cells rather than to a true fungicidal action. ${ }^{12}$ Therefore, a serum sample was included as a control in the initial studies with three selected isolates of $C$. albicans (GDHa2, GDHa11 and GDHa15). These three from a panel of $22 \mathrm{C}$. albicans isolates were chosen for further study because in initial screening assays to investigate their virulence attributes (e.g. adherence to buccal epithelial and denture acrylic surfaces, phospholipase and protease production) GDHa15, GDHa2 and GDHa11 demonstrated high, moderate and low virulence profiles, respectively (unpublished data).

The experiment with serum comprised mixing $0.25 \mathrm{ml}$ of the candidal suspension prepared as above$(2-2.5) \times 10^{6}$ yeast cells $/ \mathrm{ml}$ - with an equal volume of undiluted sterile horse serum (Gibco, Glasgow) in a 7$\mathrm{ml}$ bottle. PBS was included as a serum and BLF-free control and, the experiment was conducted as described above.

\section{Heat treatment of $B L F$}

Although Nugent and Fick ${ }^{5}$ have described the heat-stable nature of BLF, a few experiments were conducted to confirm this property. BLF from rat TR2 was incubated in a water bath at $56^{\circ} \mathrm{C}$ for $30 \mathrm{~min}$ before the assay procedure. Then the inactivated BLF $(0.25 \mathrm{ml})$ was incubated with $0.25 \mathrm{ml}$ of $C$. albicans suspension (isolates GDHa2, GDHa11 and GDH15) containing $(2-2 \cdot 5) \times 10^{6}$ yeast $/ \mathrm{ml}$ for $120 \mathrm{~min}$. Subsequently the number of cfu was estimated as described above. A suspension of $0.25 \mathrm{ml}$ of the test isolate in an 


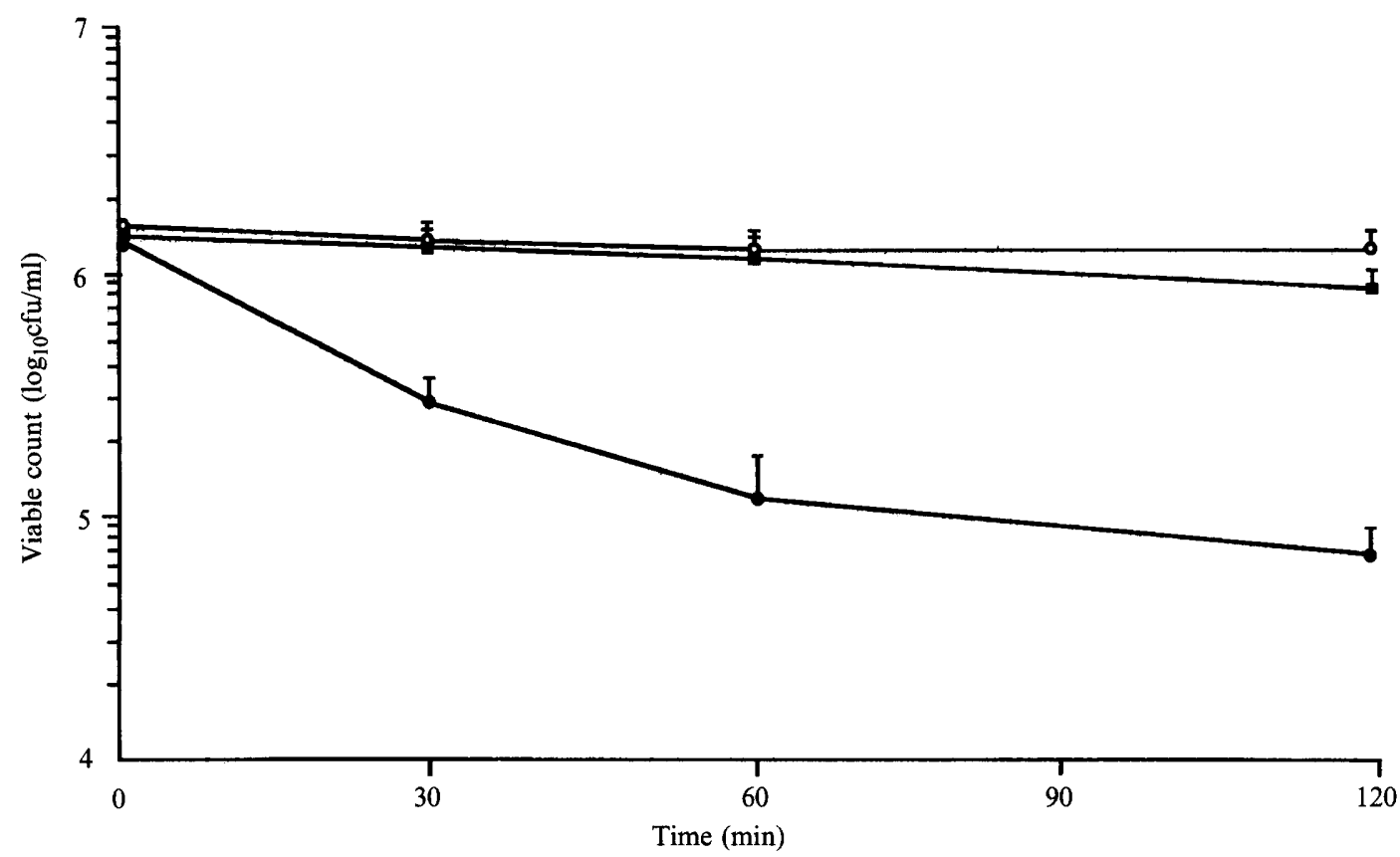

Fig. 1. The relative susceptibility of three isolates of $C$. albicans (GDHa2, GDHa11 and GDHa15) when exposed to neat BLF, horse serum or PBS for $120 \mathrm{~min}$. Each value is the mean of nine experiments (three for each isolate). $\bigcirc-\mathrm{PBS} ; \square-\mathrm{serum} ; \mathrm{O}-\mathrm{O}$ normal BLF.

equal volume of unheated BLF was included as the control on each occasion the experiment was performed.

\section{$B L F$ concentration and candidacidal activity}

To assess the relationship between the concentration of BLF and its candidacidal effect, the following experiment was performed with C. albicans GDHa15. Serial dilutions of BLF, obtained from rat TR2, ranging from neat to 1 in 1024 were prepared in 7-ml bottles containing $0.25 \mathrm{ml}$ of sterile distilled water. To each bottle, $0.25 \mathrm{ml}$ of a suspension of $C$. albicans containing $(2-2.5) \times 10^{6}$ yeast $/ \mathrm{ml}$, was added to yield a total volume of $0.5 \mathrm{ml}$ and the assay was conducted as described above. A negative control with BLF substituted by $0.25 \mathrm{ml}$ of PBS, was used in all the experiments.

\section{Assessment of BLF from different rats}

A single $C$. albicans isolate (GDHa15) was used to assess possible variations in the anti-candida activity of BLF collected from rats inoculated orally with Candida spp. and the candida-free control group. In this experiment, BLF from the seven rats in the test group and five from the control group were evaluated by the candidacidal assay described above. Briefly, $0.25 \mathrm{ml}$ of BLF and $0.25 \mathrm{ml}$ of the candidal suspension were mixed and incubated at $37^{\circ} \mathrm{C}$ for $0,30,60$ and 120 min. The resultant yields of cfu from each BLF suspension from the 12 rats were then compared.

\section{Assessment of BLF activity against different Candida spp.}

The effect of BLF from two rats (TR3 and TR4) on the following yeast species was investigated: $C$. albi- cans (22 isolates), C. glabrata (three), C. tropicalis (seven), C. parapsilosis (five), C. krusei (seven) and $C$. guilliermondii (five). The yeasts were cultured as described above and $0.25 \mathrm{ml}$ of each yeast suspension $\left(2-2.5 \times 10^{6}\right.$ yeast $\left./ \mathrm{ml}\right)$ was mixed with $0.25 \mathrm{ml}$ of BLF in a $7-\mathrm{ml}$ bottle. The suspensions were incubated at $37^{\circ} \mathrm{C}$ in an orbital incubator at $80 \mathrm{rpm}$ for $120 \mathrm{~min}$ and the assay was performed as described above.

All the foregoing experiments were repeated on three separate occasions with duplicate determinations on each occasion.

\section{Statistical analysis}

The numerical data obtained were analysed by Student's $t$-test or the analysis of variance (ANOVA) at $5 \%$ and $1 \%$ levels.

\section{Results}

\section{Fungicidal activity of $B L F$ and serum}

The effects of the incubation of three isolates of $C$. albicans with BLF, serum and PBS are shown in fig. 1 . There was a significant reduction in the number of $\mathrm{cfu}$ of Candida spp. when exposed to BLF compared with either the serum or the buffer control, at all three time intervals $(p<0.05)$. On microscopic observation of the yeast suspensions, no agglutinating or clumping yeast cells could be observed throughout the incubation period, in either the test or the control samples. However, clumping was observed, in serum samples in particular (results not shown), when a higher concentration of yeast cells- $(2-2.5) \times 10^{7}$ cells $/ \mathrm{ml}-$ was added. Therefore, a candidal suspension of $(2-2 \cdot 5) \times$ $10^{6}$ yeast $/ \mathrm{ml}$ was employed throughout the remainder 
Table I. Percentage survival of three C. albicans isolates exposed to normal and heattreated BLF from rat TR2

\begin{tabular}{|c|c|c|c|c|c|c|}
\hline \multirow{3}{*}{$\begin{array}{l}\text { Incubation } \\
\text { period } \\
\text { (min) }\end{array}$} & \multicolumn{6}{|c|}{ Percentage survival } \\
\hline & \multicolumn{2}{|c|}{$\begin{array}{l}\text { C. albicans } \\
\text { GDHa2 }\end{array}$} & \multicolumn{2}{|c|}{$\begin{array}{l}\text { C. albicans } \\
\text { GDHa11 }\end{array}$} & \multicolumn{2}{|c|}{$\begin{array}{l}\text { C. albicans } \\
\text { GDHa15 }\end{array}$} \\
\hline & Normal & Heated & Normal & Heated & Normal & Heated \\
\hline 30 & $\begin{array}{l}22 \cdot 9^{*} \\
(1 \cdot 14)\end{array}$ & $\begin{array}{l}18.1^{*} \\
(0.38)\end{array}$ & $\begin{array}{l}19 \cdot 3 \\
(1.0)\end{array}$ & $\begin{array}{l}24 \cdot 6 \\
(2 \cdot 91)\end{array}$ & $\begin{array}{l}41.3^{*} \\
(1.64)\end{array}$ & $\begin{array}{l}62 \cdot 7^{*} \\
(4 \cdot 65)\end{array}$ \\
\hline 60 & $\begin{array}{c}8.6 \\
(1 \cdot 21)\end{array}$ & $\begin{array}{c}8.1 \\
(0.43)\end{array}$ & $\begin{array}{c}8 \cdot 0^{*} \\
(0.70)\end{array}$ & $\begin{array}{l}14 \cdot 0^{*} \\
(2 \cdot 11)\end{array}$ & $\begin{array}{l}19 \cdot 4^{*} \\
(0 \cdot 70)\end{array}$ & $\begin{array}{l}31 \cdot 3^{*} \\
(1 \cdot 70)\end{array}$ \\
\hline 120 & $\begin{array}{c}5 \cdot 3 \\
(0 \cdot 27)\end{array}$ & $\begin{array}{c}6.9 \\
(0.44)\end{array}$ & $\begin{array}{c}2 \cdot 2^{*} \\
(0.15)\end{array}$ & $\begin{array}{r}7 \cdot 3^{*} \\
(0.44)\end{array}$ & $\begin{array}{r}6.2^{*} \\
(0.17)\end{array}$ & $\begin{array}{l}20.7 * \\
(1.41)\end{array}$ \\
\hline
\end{tabular}

*Asterisks indicate significant differences $(\mathrm{p}<0.05)$ in survival rates of yeasts exposed to normal and heat-treated bronchoalveolar lavage fluid.

Each value represents the mean (SEM) of three separate determinations.

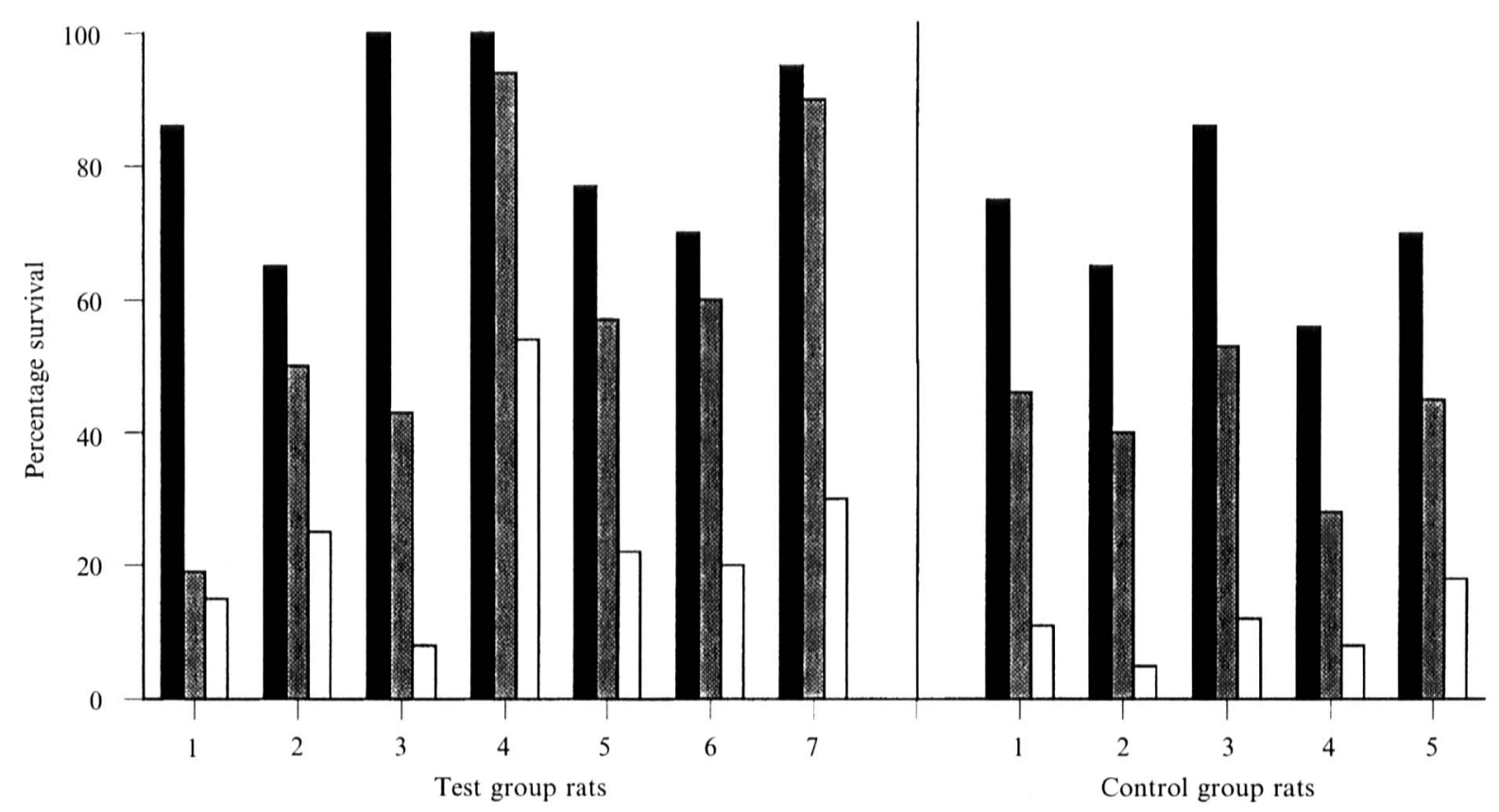

Fig. 2. The mean percentage survival (at different time intervals) of C. albicans GDHa15 when exposed to neat BLF from the test group of rats inoculated orally with $C$. albicans GDHa15 and uninoculated controls. Each bar represents the mean of three separate experiments; $30 \mathrm{~min}$; $60 \mathrm{~min} ; \square 120 \mathrm{~min}$.

of the studies. Furthermore, these pilot studies demonstrated not only the anti-candida activity but also the temporal variations in the activity of BLF.

\section{Heat treatment of BLF and fungicidal activity}

The next series of experiments was performed to assess the relative potency of normal and heat-treated BLF on three selected C. albicans isolates (GDHa2, GDHal1 and GDHa15). The results are shown in table I. Generally, heat-treated BLF (from rat TR2) was less effective in killing all three $C$. albicans isolates than normal BLF. Further comparison of the potency of the normal and heat-treated BLF revealed significantly diminished candidacidal activity of the latter, at all three time intervals $(30,60$ and $120 \mathrm{~min}$ ), with a single isolate of $C$. albicans (GDHa15), whilst the other two isolates (GDHa2 and GDHa11) were killed to a lesser extent by the heat-treated BLF (table I). There were significant differences in candidacidal activity between the buffer control and both the normal and heat-treated BLF $(p<0.05)$.

\section{Fungicidal activity of BLF in test and control rats}

The activity of BLF from all the rats was then evaluated with a single isolate of $C$. albicans (GDHa15) to ascertain variations at different time intervals between (i) the test and the control group, and (ii) different animals within the same group. As in the previous experiment, an increase in the period of incubation with BLF resulted in a reduction in the percentage of viable cells (fig. 2).

On multiple comparisons of pair analysis of the results, no intra-individual variations for BLF within the control group of rats in terms of anti-candida 


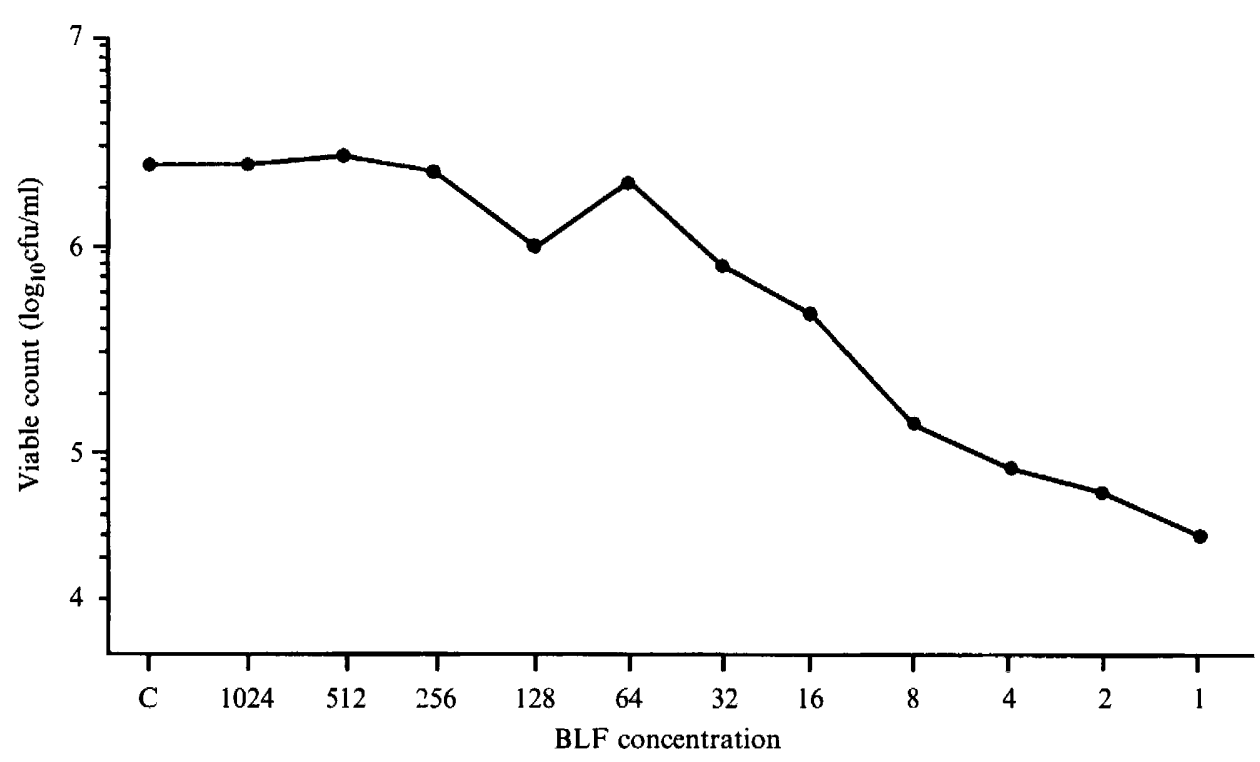

Fig. 3. The susceptibility of C. albicans GDHa 15 to varying concentrations of BLF, (TR2) after exposure for 120 min. Each point represents the mean of three separate experiments.

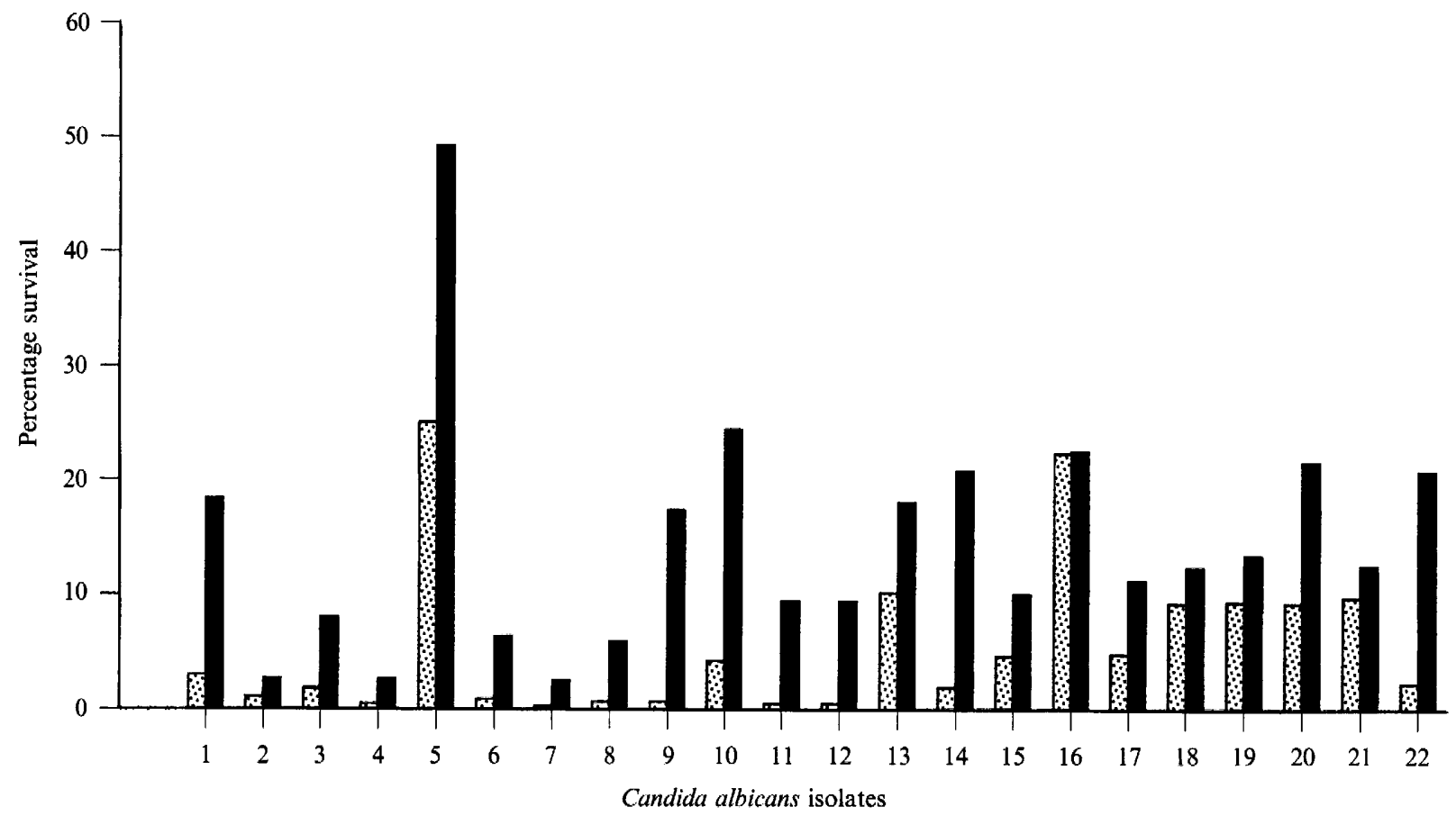

Fig. 4. The relative susceptibility (expressed as percentage survival) of 22 isolates of $C$. albicans exposed to BLF from two rats (图 R3; for $120 \mathrm{~min}$. Each bar represents the mean of three separate determinations (see also table II).

activity could be discerned. However, in the case of the test group of rats (which received a carbohydrate-rich diet, tetracycline and were challenged with C. albicans) significant individual variations in the anti-candida activity were observed $(\mathrm{p}<0.05$, fig. 2$)$. For instance, BLF from rat TR4 was less candidacidal when compared with BLF from TR1, TR2, TR3 or TR6.

When the mean percentage survival rates of the yeasts exposed to BLF from both the test and the control group of rats were compared, significant differences between the potency of BLF from in- dividual rats were seen. Thus, 12 of 35 paircomparisons demonstrated significant differences $(p<0.05$, ANOVA). Nonetheless, when the overall mean candidacidal activity of BLF from the control and the test group rats were compared no significant difference could be elicited $(p>0.05)$.

\section{Concentration of BLF and fungicidal activity}

The sensitivity of a C. albicans isolate (GDHa15) to various BLF concentrations measured by the reduc- 


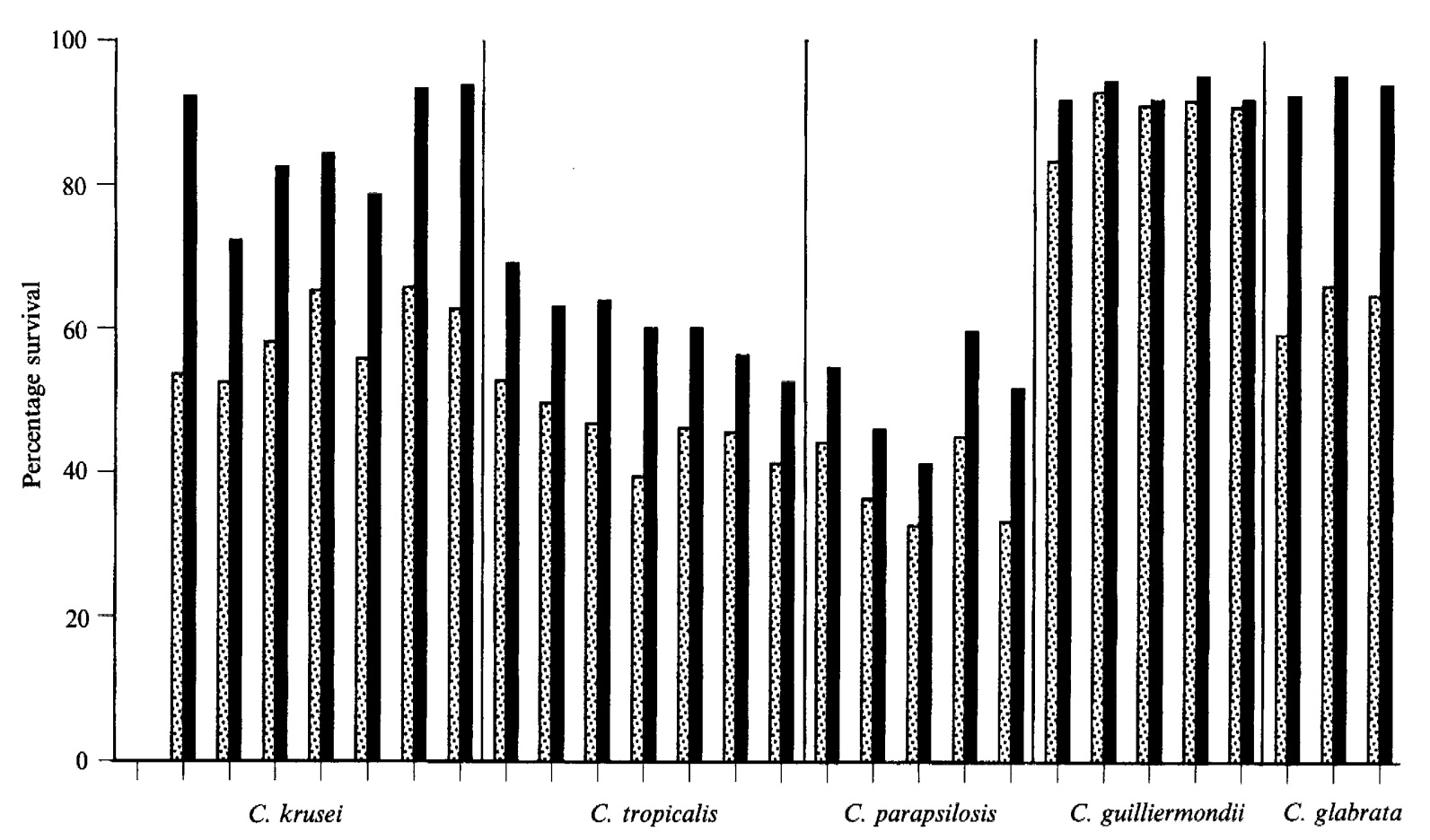

Fig. 5. The relative susceptibility (expressed as percentage survival) of 27 isolates belonging to five different $C a n d i d a$ spp. exposed to BLF from two rats (圈 R3; R4) for 120 min. Each bar represents the mean of three separate determinations (see also table II).

Table II. The candidacidal activity of BLF from rats TR3 and TR4 against a panel of Candida spp. Each isolate was assessed on three separate occasions with duplicate determinations on each occasion. The yeasts were exposed to neat BLF for $120 \mathrm{~min}$ (see also figs. 4 and 5)

\begin{tabular}{|c|c|c|c|c|c|}
\hline \multirow{2}{*}{ Candida spp. } & \multirow{2}{*}{$\begin{array}{l}\text { Number of } \\
\text { isolates }\end{array}$} & \multicolumn{3}{|c|}{ Percentage survival } & \multirow{2}{*}{$\begin{array}{l}\text { Rank order } \\
\text { of sensitivity }\end{array}$} \\
\hline & & $\begin{array}{l}\text { TR3 } \\
\text { BLF }\end{array}$ & $\begin{array}{l}\text { TR4 } \\
\text { BLF }\end{array}$ & Mean & \\
\hline C. albicans & 22 & $5 \cdot 5$ & $14 \cdot 5$ & $10 \cdot 0$ & 1 \\
\hline C. krusei & 7 & $59 \cdot 1$ & $85 \cdot 3$ & $72 \cdot 2^{*}+$ & 4 \\
\hline C. tropicalis & 7 & $45 \cdot 9$ & $60 \cdot 6$ & $53 \cdot 3^{*} \dagger$ & 3 \\
\hline C. parapsilosis & 5 & $38 \cdot 3$ & $50 \cdot 4$ & $44 \cdot 4^{* \dagger}$ & 2 \\
\hline C. guilliermondii & 5 & 89.9 & 92.9 & $91 \cdot 4^{*}$ & 6 \\
\hline C. glabrata & 3 & $63 \cdot 3$ & $93 \cdot 7$ & $78 \cdot 5^{*} \dagger$ & 5 \\
\hline
\end{tabular}

*Significant difference $(\mathrm{p}<0.001)$ in survival rate between $C$. albicans and the indicated species.

†Significant difference $(\mathrm{p}<0.05)$ in survival rate between $C$. guilliermondii and the indicated species.

tion in the cfu after exposure to the fluid (from TR2), for $120 \mathrm{~min}$ is shown in fig. 3. Results indicated that the potency of BLF persisted up to a dilution of 1 in 32 $(p<0.05)$. Subsequently, the number of cfu decreased exponentially in a dose-dependent manner.

Linear regression analysis showed a significant negative correlation between the BLF concentration and the number of $\mathrm{cfu} / \mathrm{ml}(\mathrm{p}<0.001)$.

\section{Fungicidal effect of BLF on C. albicans isolates}

The results of the next series of experiments to assess the relative potency of neat BLF, from rats TR3 and TR4, against 22 isolates of $C$. albicans (after exposure for $120-\mathrm{min}$ ) are shown in fig. 4 . There were statistically significant differences in intra-species susceptibility to BLF obtained from either rat amongst the $22 C$. albicans isolates. For instance, pair analysis of the 22 C. albicans isolates exposed to BLF from rat TR3 showed significant differences in susceptibility amongst nine pairs ( $p<0.05$, ANOVA; fig. 4$)$.

\section{Fungicidal effect of BLF on other Candida spp.}

The effect of BLF from rats TR3 and TR4 on 27 isolates belonging to five different Candida spp. demonstrated significant inter-species differences in susceptibility to BLF (fig. 5). These results, taken together with those of $C$. albicans (table II), indicate that $C$. albicans is the most susceptible to BLF, 
followed by $C$. parapsilosis and $C$. tropicalis whereas, C. krusei, C.guilliermondii and C. glabrata were highly resistant, with survival rates of $85 \cdot 3,92.9$ and $93.7 \%$, respectively. There were significant inter-species differences between the susceptibility of $C$. albicans and all other species tested $(\mathrm{p}<0.001)$, and $C$. guilliermondii and the other tested species $(\mathrm{p}<0.05)$. The remaining four Candida spp. also demonstrated significant inter-species differences to a varying extent.

Furthermore, as in the case of $C$. albicans, significant intra-species differences in susceptibility to BLF was noted with C. krusei, C. tropicalis and C. parapsilosis as exemplified by their wide range of survival rates.

\section{Discussion}

Pneumonia due to Candida spp. is uncommon despite the general increase in most types of candidosis in recent years as a consequence of the pandemic of HIV infection and the wide use of antibiotics, cytotoxic and immunosuppressive drugs. ${ }^{13}$ This observation, together with the high incidence of oropharyngeal candidosis in the latter groups ${ }^{3,14}$ and the relatively infrequent isolation of Candida spp. from the upper respiratory tract, ${ }^{13}$ point to the presence of powerful lung defence mechanisms against this opportunist pathogen.

These experiments demonstrated that murine BLF may contain potent candidacidal factor(s) effective against several Candida spp. The results confirm and extend the work of Nugent and Fick ${ }^{5}$ who uncovered the presence of a heat-stable, low mol. wt ( $c$. $29000 \mathrm{Da}$ ) protein with anti-candidal activity in murine BLF. Others too have described extracellular factors which may contribute to pulmonary defences against Candida spp. La Force et al. ${ }^{15}$ isolated two candida-agglutinating proteins from rabbit lavage fluid; one was a 10000-Da protein recovered from the phospholipid-rich fraction and the other was IgA. They postulated that yeast agglutination facilitates the extracellular fungicidal activity of alveolar macrophages, but the exact role of agglutination in pulmonary defences remains uncertain.

As agglutination of yeast cells may result in an apparent reduction in the number of CFU after exposure to BLF, giving a false impression of antifungal activity, the anti-candidal activity of BLF was compared with that of sterile horse serum. The latter was specifically chosen as it contains a heat-stable, dialysable substance called "Candida clumping factor". ${ }^{12}$ The candidacidal activity of both serum $(\mathrm{p}<$ $0.05)$ and BLF ( $p<0.001)$ significantly increased when compared with the buffer control, but to a far greater extent with BLF (fig. 1). Furthermore, highly significant differences in activity were observed between serum and BLF $(\mathrm{p}<0.001)$, at all time intervals, indicating that the reduction in number of CFU of Candida spp. after exposure to BLF is highly unlikely to be due to a clumping or agglutinating effect on yeast cells. This was futher confirmed by microscopic observation. However, it should be noted that incubation of higher concentrations of yeasts $\left(2 \times 10^{7}\right.$ yeast cells $/ \mathrm{ml}$ ) either in BLF or serum leads to agglutination, as has been demonstrated by others. ${ }^{4,12,16}$

Since heat inactivation of $\mathrm{BLF}\left(56^{\circ} \mathrm{C}\right.$ for $\left.30 \mathrm{~min}\right)$ produced a marginal reduction in anti-candida activity when compared with normal BLF, it is unlikely that heat-labile factors are of crucial importance in the killing process.

The non-specific nature of the activity of $B L F^{5}$ has been substantiated in this study by the absence of significant differences in the potency of BLF between the control and the test group of rats, the latter having been inoculated orally and infected--as demonstrated histopathologically by hyphal infiltrates in the palatal and lingual epithelium to varying degrees (unpublished data). Nonetheless, significant variations in candidacidal activity between the individual rats were observed (fig. 2). These findings suggest that the anti-candida activity of murine BLF may vary and may determine the resistance of individual animals to pulmonary candidosis. Most secretions and fluids within the mammalian host contain examples of substances that act non-specifically to suppress microbial invaders. For Candida spp., there are reports of inhibitory substances including lysozyme, ${ }^{7,17,18}$ lactoferrin ${ }^{8,19}$ and histidine-rich polypeptides or histatins, ${ }^{20,21}$ particularly concentrated in biological fluids such as saliva.

When the effect of BLF on several Candida spp. was examined, C.guilliermondii and C.glabrata were found to be the most resistant and $C$. albicans the most sensitive. This may reflect the subtle variations in the cell-wall composition between various Candida spp. ${ }^{22}$ Interestingly, the most susceptible species, $C$, albicans, is regarded as the most virulent and is the commonest isolate from the oropharyngeal region. ${ }^{23}$ Yet, the fact that pulmonary candidosis is rare indicates that the protective effect conferred by the anti-candidal activity in BLF may play an important role in the defence of the pulmonary tract.

The results of our study compare very favourably with the only other similar investigation, by Nugent and Fick. ${ }^{5}$ For instance, they reported that the blastospores of two of five Candida spp. tested were almost completely killed by incubation with BLF for $120 \mathrm{~min}$ and found considerable intra-species variations in the susceptibility of three isolates of $C$. albicans. Nonetheless, they used Swiss Webster mice, not Sprague-Dawley rats, and, mostly, a single representative isolate from each Candida spp.

Little is known about the non-specific defence mechanisms that protect the lung. The mechanism of microbial killing in the pulmonary alveoli have been studied with staphylococci, ${ }^{6,24}$ pneumococci ${ }^{25,26}$ and Escherichia coli. ${ }^{27}$ These studies with bacterial pathogens indicated that the lung has potent non-cellular defences against microbes which include the free fatty acid fraction of the surfactant, ${ }^{25,26}$ low mol. wt 
peptides ${ }^{27}$ and other heat-stable proteins. ${ }^{24}$ These data, together with those of the current study, suggest that the non-specific, antimicrobial activity of respiratory secretions may provide primary protection against low

\section{References}

1. Edwards JE, Lehrer RI, Stiehm ER, Fischer TJ, Young LS. Severe candidal infections. Clinical perspective, immune defense mechanisms, and current concepts of therapy. Ann Intern Med 1978; 89: 91-106.

2. Mawur H, Rosen PP, Armstrong D. Pulmonary disease caused by Candida species. Am J Med 1977; 63: 914-925.

3. Samaranayake LP. Host factors and oral candidosis. In: Samaranayake LP, MacFarlane TW (eds) Oral candidosis. London, Wright 1990: 66-103.

4. Nugent KM, Onofrio JM. Pulmonary tissue resistance to Candida albicans in normal and in immunosuppressed mice. Am Rev Respir Dis 1983; 128: 909-914.

5. Nugent KM, Fick RB. Candidacidal factors in murine bronchoalveolar lavage fluid. Infect Immun 1987; 55 : 541-546.

6. Nugent KM, Pesanti EL. Nonphagocytic clearance of Staphylococcus aureus from murine lungs. Infect linmun 1982; 33: 1032-1036.

7. Tobgi RS, Samaranayake LP, MacFarlane TW. In vitro susceptibility of Candida species to lysozyme. Oral Microbiol Immunol 1988; 3: 35-39.

8. Nikawa H, Samaranayake LP, Tenovuo J, Pang KM, Hamada T. The fungicidal effect of human lactoferrin on Candida albicans and Candida krusei. Arch Oral Biol 1994 (in press).

9. Lodder J. The yeasts: a taxonomic study. Amsterdam, Elsevier. 1970: 1385.

10. MacKenzie DWR. Serum tube identification of Candida albicans. J Clin Pathol 1962; 15 : 563-565.

11. Russell $\mathbf{C}$, Jones $\mathbf{J H}$. Effect of oral inoculation of Candida albicans in tetracycline-treated rats. J Med Microbiol 1973 ; 6: 275-279.

12. Louria DB, Smith JK, Brayton, RG, Buse M. Anti-Candida factors in serum and their inhibitors. 1. Clinical and laboratory observations. J Infect Dis 1972: 125: 102-114.

13. Odds FC. Candida and candidosis. 2nd edn, Philadelphia, Bailliere Tindall. 1988: 165.

14. Samaranayake LP, Holmstrup P. Oral candidiasis and human immunodeficiency virus infection. J Oral Pathol Med 1989; 18: $554-564$. intensity challenges, helping to maintain the sterility of the lower respiratory tract. Specific defence mechanisms and phagocytosis by alveolar macrophages appear to be a second line of defence.
15. La Force FM, Sharrar RG, Arai G. Characterization of yeast agglutinins in lavage fluid from lungs of rabbits. $J$ Infect Dis 1979; 140: 96-104.

16. Janke D. Zur Diagnostik der Lungenmoniliasis mit Hilfe der Serumfungistase. Artzt Wchnschr 1955; 10: 349-352.

17. Kamaya T. Lytic action of lysozyme on Candida albicans. Mycopathol Mycol Appl 1970; 42: 197-207.

18. Collins MS, Pappagianis D. Lysozyme-enhanced killing of Candida albicans and Coccidioides immitis by amphotericin B. Sabouraudia $1974 ; 12$ : $329-340$.

19. Soukka T, Tenovuo J, Lenander-Lumikari M. Fungicidal effect of human lactoferrin against Candida albicans. FEMS Microbiol Lett 1992; 90: 223-228.

20. Oppenheim FG, Xu GT, McMillan FM et al. Histatins, a novel family of histidine-rich proteins in human parotid secretions. Isolation, characterization, primary structure, and fungistatic effects on Candida albicans. $J$ Biol Chem 1988; 263: 7472-7477.

21. Pollock JJ, Denepitiya L, MacKay BJ, Iacono VJ. Fungistatic and fungicidal activity of human parotid salivary histidinerich polypeptides on Candida albicans. Infect Immun 1984; 44: 702-707.

22. Joshi KR, Gavin JB. The morphology of colony variants of three species of Candida. Sabouradia 1975; 13: 274-279.

23. Samaranayake LP. Introduction and historical aspects. In: Samaranayake LP, MacFarlane TW (eds) Oral candidosis. London, Wright. 1990: 1-9.

24. Onofrio JM, Toews GB, Lipscomb MF, Pierce AK. Granulocyte-alveolar-macrophage interaction in the pulmonary clearance of Staphylococcus aureus. Am Rev Resp Dis 1983; 127: 335-341.

25. Coonrod JD, Lester RL, Hsu LC. Characterization of the extracellular bactericidal factors of rat alveolar lining material. J Clin Invest $1984 ; 74: 1269-1279$.

26. Coonrod JD, Yoneda K. Detection and partial characterization of antibacterial factor(s) in alveolar lining material of rats. $J$ Clin Invest 1983; 71: 129-141.

27. LaForce FM, Boose DS. Sublethal damage of Escherichia coli by lung lavage. Am Rev Respir Dis 1981; 124: 733-737. 